\title{
PROTHROMBOGENIC POLYMORPHIC VARIANTS OF HEMOSTATIC AND FOLATE METABOLISM GENES IN PATIENTS WITH ASEPTIC CEREBRAL VENOUS THROMBOSIS
}

Maksimova MYu $\bowtie$, Dubovitskaya Yul, Krotenkova MV, Shabalina AA

Research Center of Neurology, Moscow, Russia

Cerebral venous sinus thrombosis (CVT) becomes the cause of stroke in less than $1 \%$ of patients. In 20-30\% of patients, the cause of thrombosis remains unclear, and thrombosis is considered idiopathic. Inherited hypercoagulable conditions significantly increase the risk of CVT. The aim of the study was to evaluate the frequency of prothrombogenic polymorphic variants of hemostatic and methionine-homocysteine metabolism genes alleles and genotypes in patients with aseptic CVT. Fifty one patients aged 18-75 with aseptic CVT were examined. The control group included 36 healthy volunteers. Neuroimaging methods included brain $\mathrm{MRI}$ in standard modes (T1, T2, T2 d-f (FLAIR), DWI) and MR venosinusography. All patients were surveyed to identify carriers of prothrombogenic polymorphic variants of hemostatic and folate metabolism genes alleles and genotypes. Prothrombogenic polymorphic variants of hemostatic genes were detected in $94 \%$ of patients, and the variants of the methionine-homocysteine metabolism genes were observed in $86 \%$ of patients. The differences between distributions of alleles and genotypes 5G6754G of the PAl-1 gene, G103T of the FXIIIA1 gene, A66G of the MTRR gene, A2756G of the MTR gene in the group of patients with CVT and in the control group were significant. Allele 4G, genotypes 4G/4G and 5G/4G of 5G6754G polymorphism of the PAl-1 gene; allele T of G103T polymorphism of the FXIIIA1 gene; allele $G$ and genotype A/G of A66G polymorphism of the MTRR gene; allele $G$ and genotype A/G of A2756G polymorphism of the MTR gene correlated with aseptic CVT. It was concluded that the gene polymorphisms 5G6754G (PAI-1), G103T (FXIIIA1), A66G (MTRR) and A2756G (MTR) carriage increased the risk of aseptic CVT and did not affect the thrombosis clinical manifestations.

Keywords: aseptic cerebral venous sinus thrombosis, prothrombogenic polymorphic variants of hemostatic and folate metabolism genes

Funding: the study was performed as a part of the public assignment of the Research Center of Neurology.

Author contribution: Maksimova MYu - concept development and study arrangement, clinical and laboratory data analysis, statistical analysis, manuscript writing; Dubovitskaya Yul — clinical examination of patients, data aquisition and primary analysis of the results; Krotenkova MV — brain MRI, MR venography and neuroimaging diagnosis of cerebral venous sinus thrombosis; Shabalina AA — laboratory analysis of prothrombogenic polymorphic variants of hemostatic and folate metabolism genes.

Compliance with ethical standards: the study was approved by the Ethics Committee of the Research Center of Neurology (protocol № 12-8/16 dated December 14, 2016). All patients submitted the informed consent to participation in the study.

$\triangle$ Correspondence should be addressed: Marina Yu. Maximova

Volokolamskoye Shosse, 80, Moscow, 125367; ncnmaximova@mail.ru

Received: 19.08.2019 Accepted: 06.10.2019 Published online: 16.10.2019

DOI: $10.24075 /$ brsmu.2019.065

\section{ПРОТРОМБОГЕННЫЕ ПОЛИМОРФНЫЕ ВАРИАНТЫ ГЕНОВ СИСТЕМЫ ГЕМОСТАЗА И ФОЛАТНОГО ОБМЕНА ПРИ АСЕПТИЧЕСКОМ ТРОМБОЗЕ ЦЕРЕБРАЛЬНЫХ ВЕНОЗНЫХ СИНУСОВ}

\author{
М. Ю. Максимова , Ю. И. Дубовицкая, М. В. Кротенкова, А. А. Шабалина
}

Научный центр неврологии, Москва, Россия

\begin{abstract}
Тромбоз церебральных венозных синусов (ТЦВС) составляет менее 1\% всех случаев инсульта. В 20-30\% случаев причина тромбоза остается неясной и его расценивают как идиопатический. Врожденные гиперкоагуляционные состояния значительно увеличивают риск развития ТЦВС. Целью исследования было оценить частоту аллелей и генотипов протромбогенных полиморфных вариантов генов гемостаза и метионин-гомоцистеинового обмена при асептическом ТЦВС. Обследован 51 пациент с асептическим ТЦВС в возрасте от 18 до 75 лет. Контрольную группу составили 36 здоровых добровольцев. Нейровизуализационные методы включали MPT головного мозга в стандартных режимах (T1, T2, T2 d-f (FLAIR), ДВИ) и MPвеносинусографию. Всем пациентам проводили исследование на носительство аллелей и генотипов протромбогенных полиморфных вариантов генов системы гемостаза и фолатного обмена. Протромбогенные полиморфные варианты генов системы гемостаза были выявлены в 94\% случаев, генов метионин-гомоцистеинового обмена - в 86\% случаев. Получены достоверные различия при исследовании распределения аллелей и генотипов 5G6754G гена PAI-1, G103T гена FXIIIA1, A66G гена MTRR, A2756G гена MTR в группе больных ТЦВС по сравнению с группой здоровых добровольцев. Аллель 4G, генотипы 4G/4G и 5G/4G полиморфизма 5G6754G гена PAl-1; аллель Т полиморфизма G103Т гена FXIIIA1; аллель G и генотип A/G полиморфизма A66G гена MTRR; аллель G и генотип AVG полиморфизма A2756G гена MTR связаны с развитием асептического ТЦвC. Сделан вывод, что носительство полиморсизма генов PAl-1 (5G6754G), FXIIIA1 (G103T), MTRR (A66G) и MTR (A2756G) повышает риск развития асептического TЦВC и не влияет на клинические проявления тромбоза.
\end{abstract}

Ключевые слова: асептический тромбоз церебральных венозных синусов, протромбогенные полиморфные варианты генов гемостаза и фолатного обмена

Финансирование: работа выполнена в рамках государственного задания ФГБНУ НЦН.

Информация о вкладе авторов: М. Ю. Максимова - разработка концепции и организация исследования, обобщающий анализ клинических и лабораторных данных, статистическая обработка, написание статьи; Ю. И. Дубовицкая - проведение клинического обследования пациентов, сбор и первичный анализ полученных результатов; М. В. Кротенкова - проведение МРТ головного мозга, МР-веносинусограсии и нейровизуализационной диагностики тромбоза церебральных венозных синусов; А. А. Шабалина - проведение лабораторного исследования протромбогенных полиморфных вариантов генов гемостаза и фолатного обмена.

Соблюдение этических стандартов: исследование одобрено этическим комитетом ФГБНУ «Научный центр неврологии» (протокол № 12-8/16 от 14 декабря 2016 г.). Все пациенты подписали добровольное информированное согласие на участие в исследовании.

$\checkmark$ Для корреспонденции: Марина Юрьевна Максимова

Волоколамское ш., д. 80, г. Москва, 125367; ncnmaximova@mail.ru

Статья получена: 19.08.2019 Статья принята к печати: 06.10.2019 Опубликована онлайн: 16.10.2019

DOI: $10.24075 /$ vrgmu.2019.065 
Cerebral venous sinus thrombosis (CVT) becomes the cause of stroke in less than $1 \%$ of patients [1, 2]. In $20-30 \%$ of patients, the cause of thrombosis remains unclear, and thrombosis is considered idiopathic [3]. Inherited hypercoagulable conditions significantly increase the risk of CVT $[4,5]$.

The incidence of cerebral venous sinus thrombosis (CVT) is 1.3 per 100,000 adults per year. Onset may occur at any age, but the highest incidence is noted in people aged 31-50 [6]. Among patients, the women prevail [7]. Despite the improvement of diagnostic and treatment methods, the CVT patients' mortality remains high and reaches 30\% [8].

CVT can be either septic (as a result of complications of purulent otitis media, mastoiditis, sinusitis) or aseptic (occurs as a complication of numerous diseases that increase the tendency to form a blood clot).

Many factors are involved in the development of aseptic CVT: severe dehydration, cardiac disorders (congenital heart defects, heart failure, artificial cardiac pacemaker), cancer, pregnancy, diabetes mellitus, hormonal drugs usage (contraceptive pills, hormone replacement therapy), nephrotic syndrome, polycythemia, essential thrombocytosis, antiphospholipid syndrome, connective tissue disorders and vasculitis (systemic lupus erythematosus, granulomatosis with polyangiitis, temporal arteritis, Behcet's disease), inflammatory bowel disease (Crohn's disease, ulcerative colitis), brain injury, congenital or acquired hemostasis alterations [9-12].

Hereditary thrombophilia is a significant risk factor for aseptic CVT. The most studied are polymorphic variants of factor $\mathrm{V}$ (Leiden) and prothrombin genes [13]. Thus, correlation was observed between the risk of CVT and the clotting factor $\mathrm{V}(\mathrm{OR}$ 4.3; 95\% Cl - 1.5-12.3) and prothrombin genes (OR 3,6; 95\% Cl - 1,0-13,1) polymorphisms [14]. In another study, prothrombin gene polymorphism (A replaced with $\mathrm{G}$ at position 20210) was found in 19\% of patients with CVT [15]. Correlation between the presence of the Leiden mutation and a 5-fold increase in the risk of CVT was confirmed [13]. Analysis of 26 case-control type studies demonstrated that the occurrence of the clotting factor $V$ gene polymorphism (Leiden/G1691A) leaded to 2.4 fold increase of the risk of CVT (95\% Cl - 1.75-3.30; $p<0.00001$ ), and the occurrence of the prothrombin gene polymorphism (G20210A) leaded to 5.48 fold increase of the CVT risk (95\% Cl - 3.88-7.74; $p<0.00001)$ [16].

Significant polymorphism of clinical manifestations, the absence of pathognomonic symptoms, as well as a variety of options for the onset, course, and localization of thrombosis make the clinical recognition of CVT difficult. Possibilities of CVT early diagnosis significantly expanded due to the neuroimaging methods (CT and MRI) $[2,17,18]$. Currently, MR venosinusography is one of the most reliable methods for the CVT diagnosis [19]. In up to $63 \%$ of patients, CVT is complicated by cerebral edema and the formation of necrosis foci with the addition of hemorrhagic component (37.57\% of patients) [20]. In such a situation, these foci of necrosis are not infarcts, but arise as a result of the venous outflow slowdown, edema, hypoxia of brain tissue followed by diapedesis of red blood cells and leukocytes through necrotic walls of capillaries and microvessels. The factors predisposing to development of necrosis foci and hematomas in patients with CVT include the female sex, epileptic seizure, impaired consciousness, rapidly spreading thrombosis involving two or more venous sinuses [2, 8, 20].

Often, CVT is suppressed, it is detected unexpectedly by physician during CT or MRI of the brain. For most patients with $\mathrm{CVT}$, a mismatch between the general condition of the patient and the neuroimaging manifestations of the disease is typical $[17,21]$.
Early diagnosis and well-organized treatment of aseptic $\mathrm{CVT}$ in the vast majority of patients leads to clinical recovery. Later, a decrease in the frequency of recurrent thrombosis depends on the timely identification of the thrombosis causes. Almost all researchers agree that recurrent CVT is more severe than the first diagnosed, and its prognosis is much worse.

The aim of the study was to evaluate the frequency of the prothrombogenic polymorphic variants of hemostatic and methionine-homocysteine metabolism genes alleles and genotypes in patients with aseptic CVT.

\section{METHODS}

In 2016-2019, 51 patients with aseptic CVT were examined in the 2nd Department of Neurology of the Research Center of Neurology (20 men and 31 women, the average age of the patients was $42.2 \pm 13.1)$. Twenty eight patients were hospitalized in the acute phase of the disease. In 23 patients, the duration of thrombosis was 1-10 months. Control group included 36 healthy volunteers (14 men and 22 women, their average age was $44.7 \pm 10.4)$. The groups under study were comparable by gender and age. Inclusion criteria: 1) acute aseptic CVT confirmed by neuroimaging data; 2) pre-existing aseptic CVT confirmed by neuroimaging data; 3) patients aged 18-75. Exclusion criteria: 1) septic CVT; 2) lower-extremity deep vein thrombosis (DVT) and pulmonary embolism (PE); 3) atherothrombosis involving cerebral arteries, lower limb arteries; 4) other (nonvascular) nervous system diseases; 5) decompensated comorbidities.

In all CVT patients, a detailed study of complaints, general and family history data, the clinical picture of the disease and medical documentation was performed, somatic and neurological statuses were evaluated.

For CVT diagnosis, each patient underwent brain MRI using the Magnetom Verio (Siemens; Germany) and Magnetom Symphony (Siemens; Germany) systems with 3T (Tesla) and 1.5T magnetic field strength respectively. MRI of the brain was performed in the sagittal, axial and coronal planes in T1, T2, T2 d-f (FLAIR), DWI modes with a slice thickness of 1, 3 and $5 \mathrm{~mm}$. Later the images of the cerebral veins and venous sinuses were obtained using $\mathrm{MRI}$ in the venosinusography mode. Only after a comprehensive evaluation and a detailed study of the neuroimaging results obtained using standard modes and venosinusography, the CVT diagnosis was considered confirmed. Standard modes, T2, T2-FLAIR, were used for assessment of brain tissue focal lesions and for exclusion of other possible pathologies. Image evaluation was performed using the eFilm Workstation software (Merge Healthcare; USA).

Measurement of the hemostasis parameters (fibrinogen level, fibrinolytic activity level, partial thromboplastin time (PTT)) was performed using the ACL-9000 Coagulation Analyzer (Instrumentation Laboratory; USA).

Quantitative determination of D-dimer was carried out by the specific antigen-antibody reaction based immunochemical method using the immunoturbidimetric latex-agglutination assay (Instrumentation Laboratory; USA).

The level of homocysteine in the blood was determined by enzyme immunoassay using the diagnostic kits (AXIS; Norway) and the Immulite 2000 Immunoassay System (Siemens; USA).

DNA diagnostics of prothrombotic polymorphic gene variants was performed using polymerase chain reaction (PCR).

Detection of mutations (polymorphisms) in the human genome was carried out using the DNA-Technology kit (Russia). The patient's genomic DNA was isolated from whole blood 
(EDTA tube) using NC sample, the DNA extraction reagent kit (DNA-Technology; Russia).

Two amplification reactions were simultaneously carried out with a sample of isolated DNA using two pairs of allelespecific primers. Real-time PCR was used for simultaneous amplification and for measuring of the studied DNA molecule amount (DTlite Real-Time PCR System; DNA-Technology; Russia). The DNA-Technology (Russia) commercial kits were used. The analysis results were represented by three types of decisions: a) allele 1 homozygote; b) heterozygote; c) allele 2 homozygote.

Studied prothrombogenic polymorphic variants of hemostatic and folate metabolism genes list:

- prothrombin gene, Fll (c.G20210A);

- coagulation factor $V$ gene, $F V$ (c.G1691A);

- coagulation factor VII gene, FVII (c.G10976A);

- activated factor XIII (fibrinase) gene, FXIIIA1 (c.G103T);

- fibrinogen beta gene, FGB (c.G455A);

- plasminogen activator inhibitor gene, PAl-1 (c.5G6754G);

- Integrin alpha (Gp1a glycoprotein) gene, ITGA2 (c.C807T);

- Platelet fibrinogen receptor (Gp3a glycoprotein) gene, ITGB3 (c.T1565C);

- methylenetetrahydrofolate reductase gene, MTHFR (c.C677T);

- methylenetetrahydrofolate reductase gene, MTHFR (c.A1298C);

- methionine synthase gene, MTR (c.A2756G);

- methionine synthase reductase gene, MTRR (c.A66G).

Statistical analysis was performed using the IBM SPSS Statistics software, v.23 (IBM Corporation; Russia). Nominal data were described with absolute values and percentages. For categorical data analysis the contingency tables were used. The significance level was taken equal to 0.05 in all comparisons.

Frequency of allele and genotype variants $(f)$ was calculated by the following formula:

$$
\begin{aligned}
& f=\frac{n}{2 N}-\text { allele frequency, } \\
& f=\frac{n}{N}-\text { genotype frequency, }
\end{aligned}
$$

where $n$ was the variant (allele or genotype) occurrence, $N$ was the sample size.

The significance of differences in the allele and genotype frequencies between the studied groups was evaluated using the $\chi^{2}$ criterion.

To assess the relative risk, the odds ratio (OR) and its confidence interval $(\mathrm{Cl})$ calculations were used at a confidence level of $95 \%$.

$$
\mathrm{OR}=\frac{(a+d)}{(b+c)},
$$

where a was the frequency of the studied allele (genotype) in the treatment group; $b$ was the frequency of the allele in the control group; $c$ was the sum of other alleles (genotypes) frequencies in the treatment group; $d$ was the sum of other alleles (genotypes) frequencies in the control group.

\section{RESULTS}

Isolated CVT was observed in 14 patients (27.5\%). In other 37 patients $(72.5 \%)$ multiple thrombosis was detected involving two or more venous sinuses.

Left transverse sinus thrombosis was detected in 28 patients (54.9\%), left sigmoid sinus thrombosis in 26 patients
(51\%), right transverse sinus thrombosis in 21 patient (41.2\%), right sigmoid sinus thrombosis in 14 patients (27.5\%), superior sagittal sinus thrombosis in 11 patients (21.6\%), inferior sagittal sinus thrombosis in 4 patients $(7.8 \%)$, tentorial sinus in 3 patients (5.9\%), and left cavernous sinus thrombosis in 1 patient.

Among patients with thrombosis of individual venous sinuses, 5 patients $(35.7 \%)$ were diagnosed with thrombosis of the left transverse sinus, 5 patients $(35.7 \%)$ were diagnosed with thrombosis of the left sigmoid sinus, 3 patients (21.4\%) were diagnosed with thrombosis of the right transverse sinus, and 1 patient was diagnosed with thrombosis of the superior sagittal sinus.

In 4 women, CVT occurred after abortion, in 1 woman onset took place 9 days after delivery, in 7 women (22.6\%) CVT developed while taking hormonal drugs (contraceptives). A history of inflammatory diseases of the paranasal sinuses was observed in 3 women and 1 man. Aseptic CVT was confirmed by the absence of systemic inflammatory reactions and inflammatory changes of the laboratory blood parameters.

Among all CVT patients, the focal necrosis in brain tissue caused by thrombosis was observed in 14 patients (27.5\%).

Diffuse headache was the chief complaint, which was observed in 45 patients (88.2\%). A typical feature of the headache was its worsening after being in a horizontal position. Unsystematic dizziness was noted in $27.5 \%$ of patients; it was constant, independent of body position. Nausea occurred in $23.5 \%$ of patients. In 7 patients (13.7\%), thrombosis began with impaired consciousness. Convulsive seizures were observed in 5 patients (9.8\%): focal motor seizures in 2 patients and generalized tonic-clonic seizures in 3 patients. In 9.8\% of patients, the meningitis symptoms were noted. Impaired motor function was detected in 3 patients (5.9\%): hemiplegia in 1 patient, mild or moderate decrease in muscle strength in the limbs in 2 patients. Speech problems were represented by mild motor aphasia in 4 patients (7.8\%).

When calculating the correlation coefficients, a relationship was found between brain tissue focal lesions and the development of convulsive seizures (correlation coefficient $r=0.4 ; p<0.01$ ), motor function impairment (correlation coefficient $r=0.5 ; p<0.01$ ), speech problems (correlation coefficient $r=0.5 ; p<0.01$ ), and depression of consciousness (correlation coefficient $r=0.5 ; p<0.01$ ).

Statistical analysis revealed correlation of superior sagittal sinus thrombosis with the development of a convulsive seizure (correlation coefficient $r=0.4 ; p<0.01$ ), as well as impaired venous outflow (correlation coefficient $r=0.5 ; p<0.01$ ). It also revealed correlation of tentorial sinus thrombosis with the depression of consciousness (correlation coefficient $r=0.3$; $p<0.01)$.

\section{Hemostasis parameters}

In the group of patients with CVT the fibrinogen level was $3.7 \mathrm{~g} / \mathrm{l}[2.2 ; 6.8$ ] (in the control group it was $3.8 \mathrm{~g} / \mathrm{l}$ [2.9; 5.0$]$ ); activated partial thromboplastin time was $29.5 \mathrm{~s}$ [22.5; 36.2] (in the control group it was $28.7 \mathrm{~s}$ [26.5; 29.9]); antithrombin III level was 112 [98; 119] (in the control group it was 115 [107; 126]); C protein level was 134\% [125; 148] (in the control group it was 143\% [125; 165]); D-dimer level did not exceed $0.5 \mathrm{\mu g} / \mathrm{ml}$. The fibrinogen level increase over $5.5 \mathrm{mmol} / \mathrm{I}$ was detected in one patient. Hemostasis parameters of the CVT patients did not differ significantly from the hemostasis parameters of the control group patients. 
Homocysteine level in the blood plasma of CVT patients was $16.2 \mu \mathrm{mol} / \mathrm{l}[14.6 ; 17.7$ ] (in the control group it was 7.7 [5.6; 10.9]; $p<0.05)$.

\section{Prothrombogenic polymorphic variants of hemostasis and folate metabolism genes}

Molecular genetic testing for detection of prothrombogenic polymorphic variants of hemostatic genes (Table 1) and methionine-homocysteine metabolism genes (Table 2) was carried out in 51 patients with aseptic CVT.

Homozygous (4G/4G) allele $4 \mathrm{G}$ at the -675 position of the PAl-1 gene was detected in 11 patients (22.4\%). Homozygous allele 103T of the FXIIIA1 gene was detected in 3 patients, homozygous allele 807T of the ITGA2 gene was present in 3 patients. Two patients were the 455A allele of the FGB gene homozygous carriers, 1 patient was the 10976A allele of the FVII gene carrier, and 1 patient was the 1565C allele of the ITGB3 gene carrier. Combination of two alleles in a homozygous state was detected in 2 patients. In the first of them the combination of homozygous 10976A allele of the FVII gene and 6754G allele of plasminogen activator inhibitor gene PAl-1 was observed. In the other of them the combination of homozygous 103T allele of the FXIIIA1 gene and 6754G allele of the plasminogen activator inhibitor gene PAl-1 was present. No patients with homozygous 1691A allele of the FV Leiden and 20210A allele of the Fll gene were revealed.

Heterozygous allele $4 \mathrm{G}$ at the -675 position of the PAI- 1 gene was detected in 28 patients (57.1\%). Isolated polymorphic variant of the PAl-1 gene (c. 5G6754G) in the heterozygous state was present in 9 patients (19\%). Seventeen patients (34.7\%) were heterozygous carriers of $455 \mathrm{~A}$ of the FGB gene. Thirteen patients $(26.5 \%)$ were carriers of $10976 \mathrm{~A}$ allele of the FVII gene, 103T allele of the FXIIIA1 gene, and 1565C allele of the ITGB3 gene. Polymorhic variant 807T of the ITGA2 gene in the heterozygous state was observed in 9 patients (18.4\%). Polymorhic variant $1691 \mathrm{~A}$ of the $\mathrm{FV}$ Leiden gene in the heterozygous state was present in 3 patients (5.9\%). Two patients (4\%) were heterozygous carriers of 20210A allele of the Fll gene.

The frequency distribution of hemostasis genes prothrombogenic polymorphic variants alleles and genotypes could be found in Table 1.

Alleles $5 \mathrm{G}$ and $4 \mathrm{G}$ of the PAl-1 gene frequency was 48 $(49 \%)$ and $50(51 \%)$ in the treatment group, in the control group it was $59(82 \%)$ and $13(18 \%)$. According to the calculated odds ratio, $4 \mathrm{G}$ allele increases the risk of $\mathrm{CVT}$ by more than 4 times $\left(\chi^{2}=19.337 ; p<0.001 ; O R=4.728 ; 95 \% \mathrm{Cl}-2.303-\right.$ 9.706). Homozygous $4 \mathrm{G} / 4 \mathrm{G}$ polymorphism increases the risk of CVT by 10.1 times $\left(\chi^{2}=6.623 ; p=0.011 ; \mathrm{OR}=10.132+\right.$ $1.070 ; 95 \% \mathrm{Cl}-1.243-82.573)$, and heterozygous $5 \mathrm{G} / 4 \mathrm{G}$ polymorphism increases the risk of the disease by 3.03 times $\left(\chi^{2}=5.908 ; p=0.016 ; \mathrm{OR}=3.030+0.463 ; 95 \% \mathrm{Cl}-1.223-\right.$ 7.507).

Comparative analysis of the alleles of FXIIIA1 gene G103T polymorphism frequencies in patients of the treatment group and control group revealed statistically significant differences. Alleles $\mathrm{G}$ and T of the FXIIIA1 gene occurrence was 79 (80.6\%) and $19(19,4 \%)$ in the CVT patients group, and 67 (93\%) and 5 $(7 \%)$ in the control group. Thus, the frequency of $103 \mathrm{~T}$ allele of the FXIIIA1 gene in patients with CVT significantly exceeds the frequency of the allele in the group of healthy people $\left(\chi^{2}=5.3\right.$; $p=0.022)$. According to the calculated odds ratio, the presence of T allele in the FXIIIA1 gene increases the risk of CVT by more than 3 times $(\mathrm{OR}=3.223 ; 95 \% \mathrm{Cl}-1.142-9.095)$.
There were no differences in the allele and genotype frequencies distribution of the Fll (c.G20210A), FV (c.G1691A), FVII (c.G10976A), FGB (c.G455A), ITGA2 (c.C807T), ITGB3 (c.T1565C), MTHFR (c.C677T), MTHFR (c.A1298C) genes between patients with CVT and healthy volunteers.

Among patients with polymorphic variants of methioninehomocysteine metabolism genes, 66G allele of the MTRR gene in a homozygous state was detected in 5 patients (10.9\%). Three patients (6.8\%) were homozygous carriers of 677 T allele of the MTHFR gene, and 2 patients (4.2\%) were carriers of $1298 \mathrm{C}$ allele of the MTHFR gene. In one patient, the combination of the homozygous 1298C allele of the MTHFR gene and $66 \mathrm{G}$ allele of the MTRR gene was observed. No patients were homozygous carriers of $2756 \mathrm{G}$ allele of the MTR gene.

Sixteen patients (36.4\%) were identified as heterozygous carriers of $677 \mathrm{~T}$ allele of the MTHFR gene, 19 patients (41.3\%) as carriers of 66G allele of the MTRR gene, 18 patients (39.1\%) as carriers of $2756 \mathrm{G}$ allele of the MTR gene, and 9 patients (18.8\%) as carriers of $1298 \mathrm{C}$ allele of the MTHFR gene.

Isolated polymorphic variant of the MTRR gene (c.A66G) in heterozygous state was present in 7 patients (17\%).

In 3 patients (7\%), the isolated polymorphic variant of the MTR gene (c.A2756G) in heterozygous state was identified.

Among 19 patients who were identified as heterozygous carriers of $66 \mathrm{G}$ allele of the MTRR gene, in 9 patients (47\%), the heterozygous variant of $1298 \mathrm{C}$ allele of the MTHFR gene was also detected.

The frequency values for individual polymorphic variants of methionine-homocysteine metabolism genes are presented in Table 2.

According to data obtained, the frequency of alleles $A$ and $\mathrm{G}$ of the MTRR gene (c.A66G) in the treatment group was 63 (68.5\%) and 29 (31.5\%). The frequency of these alleles in the control group was 64 (89\%) and 8 (11\%) respectively. The G allele frequency differences between the group of patients with CVT and the group of healthy people were significant $\left(x^{2}=9.631 ; p=0.002 ; \mathrm{OR}=3.683 ; 95 \% \mathrm{Cl}-1.564-8.672\right)$. Allele $\mathrm{G}$ increased the risk of CVT by 3.68 times $\left(\chi^{2}=9.631\right.$; $p=0.002 ; \mathrm{OR}=3.683 \pm 0.437 ; 95 \% \mathrm{Cl}-1.564-8.672)$. The presence of $A / G$ polymorphism increased the risk of CVT by 3.5 times $\left(\chi^{2}=5.784 ; p=0.017 ; \mathrm{OR}=3.519+0.538 ; 95 \%\right.$ $\mathrm{Cl}-1.225-10.104)$.

Allele G of A2756G polymorphism of the MTR gene frequency in the group of patients with CVT was significantly higher than in the control group (18 (19.6\%) against $6(8 \%)$; $\left.\chi^{2}=4.079 ; p=0.044\right)$, and the frequency of allele $A$ was significantly lower $\left(74(80,4 \%)\right.$ against 66 (92\%); $\chi^{2}=4.079$; $p=0.044)$. The odds ratio calculation demonstrated that allele $\mathrm{G}$ of $\mathrm{A} 2756 \mathrm{G}$ polymorphism correlated with $\mathrm{CVT}(\mathrm{OR}=2.676 \pm$ $0.501 ; 95 \% \mathrm{Cl}-1.002-7.142)$. In patients with CVT, the frequency of $A / G$ heterozygous genotypes was significantly higher than in the control group $\left(\chi^{2}=4.923 ; p=0.027\right.$; $\mathrm{OR}=$ $=3.214 \pm 0.540 ; 95 \% \mathrm{Cl}-1.116-9.257)$.

When performing the clinical molecular analysis, no significant correlation between the CVT clinical features and the identified prothrombogenic polymorphic gene variants was revealed.

Isolated CVT without any PAl-1 gene polymorphisms (c.5G6754G) was diagnosed in 1 patient, and isolated CVT with PAl-1 polymorphisms in the homozygous or heterozygous state was diagnosed in 13 patients (33\%). Multiple CVT without any $P A /-1$ gene polymorphisms was detected in 9 patients (90\%), and multiple CVT with PAl-1 polymorphisms in the homozygous or heterozygous state was identified in 26 (67\%) patients $(p=0.244)$. 
Table 1. Frequency of alleles and genotypes of the hemostasis genes prothrombogenic polymorphic variants

\begin{tabular}{|c|c|c|c|c|c|c|}
\hline \multicolumn{7}{|c|}{ Prothrombin gene FII (c.G20210A) } \\
\hline & \multirow{2}{*}{$n$} & \multicolumn{2}{|c|}{ Allele frequency } & \multicolumn{3}{|c|}{ Genotype frequency } \\
\hline & & G & A & $\mathrm{G} / \mathrm{G}$ & $\mathrm{G} / \mathrm{A}$ & $\mathrm{A} / \mathrm{A}$ \\
\hline CVT patients & 50 & $98(98 \%)$ & $2(2 \%)$ & $48(96 \%)$ & $2(4 \%)$ & $0(0 \%)$ \\
\hline Control group & 36 & $71(99 \%)$ & $1(1 \%)$ & $35(97.2 \%)$ & $1(2.8 \%)$ & $0(0 \%)$ \\
\hline \multicolumn{7}{|c|}{ Coagulation factor $\mathrm{V}$ gene, $F V($ c.G1691A) } \\
\hline & \multirow{2}{*}{$n$} & \multicolumn{2}{|c|}{ Allele frequency } & \multicolumn{3}{|c|}{ Genotype frequency } \\
\hline & & G & A & $\mathrm{G} / \mathrm{G}$ & $\mathrm{G} / \mathrm{A}$ & $\mathrm{A} / \mathrm{A}$ \\
\hline CVT patients & 51 & 99 (97.1\%) & $3(2.9 \%)$ & $48(94.1 \%)$ & $3(5.9 \%)$ & $0(0 \%)$ \\
\hline Control group & 36 & $72(100 \%)$ & $0(0 \%)$ & $36(100 \%)$ & $0(0 \%)$ & $0(0 \%)$ \\
\hline \multicolumn{7}{|c|}{ Coagulation factor VII gene, FVII (c.G10976A) } \\
\hline & \multirow{2}{*}{$n$} & \multicolumn{2}{|c|}{ Allele frequency } & \multicolumn{3}{|c|}{ Genotype frequency } \\
\hline & & $G$ & A & $\mathrm{G} / \mathrm{G}$ & $\mathrm{G} / \mathrm{A}$ & $\mathrm{A} / \mathrm{A}$ \\
\hline CVT patients & 49 & $83(84.7 \%)$ & $15(15.3 \%)$ & $35(71.4 \%)$ & $13(26.5 \%)$ & $1(2 \%)$ \\
\hline Control group & 36 & 66 (92\%) & $6(8 \%)$ & $30(83.3 \%)$ & $6(16.7 \%)$ & $0(0 \%)$ \\
\hline \multicolumn{7}{|c|}{ Activated factor XIII (fibrinase) gene, FXIIIA1 (c.G103T) } \\
\hline & \multirow{2}{*}{$n$} & \multicolumn{2}{|c|}{ Allele frequency } & \multicolumn{3}{|c|}{ Genotype frequency } \\
\hline & & $\mathrm{G}^{*}$ & $T^{* *}$ & $\mathrm{G} / \mathrm{G}$ & $\mathrm{G} / \mathrm{T}$ & $T / T$ \\
\hline CVT patients & 49 & $79(80.6 \%)$ & 19 (19.4\%) & $33(67.3 \%)$ & $13(26.5 \%)$ & $3(6.1 \%)$ \\
\hline Control group & 36 & $67(93 \%)$ & $5(7 \%)$ & $31(86.1 \%)$ & $5(13.9 \%)$ & $0(0 \%)$ \\
\hline
\end{tabular}

Note: * $-\chi^{2}=5.3 ; p=0.022 ; \mathrm{OR}=0.310 ; 95 \% \mathrm{Cl} 0.110-0.876$

${ }^{* *}-\chi^{2}=5.3 ; p=0.022 ; \mathrm{OR}=3.223+0.529 ; 95 \% \mathrm{Cl} 1.142-9.095$

\begin{tabular}{|l|c|c|c|c|c|c|}
\hline \multicolumn{6}{|c|}{ Plasminogen activator inhibitor gene, PAl-1 (c.5G6754G) } \\
\hline & $n$ & \multicolumn{2}{|c|}{ Allele frequency } & \multicolumn{4}{|c|}{ Genotype frequency } \\
\cline { 4 - 8 } & & $5 \mathrm{G}^{*}$ & $4 \mathrm{G}^{\star \star}$ & $5 \mathrm{G} / 5 \mathrm{G}^{\star \star \star}$ & $5 \mathrm{G} / 4 \mathrm{G}^{\star \star \star \star}$ & $4 \mathrm{G} / 4 \mathrm{G}^{\star \star \star \star \star}$ \\
\hline CVT patients & 49 & $48(49 \%)$ & $50(51 \%)$ & $10(20.4 \%)$ & $28(57.1 \%)$ & $11(22.4 \%)$ \\
\hline Control group & 36 & $59(82 \%)$ & $13(18 \%)$ & $24(66.7 \%)$ & $11(30.6 \%)$ & $1(2.8 \%)$ \\
\hline
\end{tabular}

Note: ${ }^{*}-\chi^{2}=19.337 ; p<0.001 ; \mathrm{OR}=0.212 ; 95 \% \mathrm{Cl} 0.103-0.434$;

${ }^{* \star}-\chi^{2}=19.337 ; p<0.001 ; \mathrm{OR}=4.728+0.367 ; 95 \% \mathrm{Cl} 2.303-9.706$

${ }^{* \star *}-\chi^{2}=18.503 ; p<0.001 ; \mathrm{OR}=0.128 ; 95 \% \mathrm{Cl} 0.048-0.302$

${ }_{* \star * *}-\chi^{2}=5.908 ; p=0.016 ; \mathrm{OR}=3.030+0.463 ; 95 \% \mathrm{Cl} 1.223-7.507$

${ }^{* \star * \star *}-\chi^{2}=6.623 ; p=0.011 ; \mathrm{OR}=10.132+1.070 ; 95 \% \mathrm{Cl} 1.243-82.573$.

\begin{tabular}{|c|c|c|c|c|c|c|}
\hline \multicolumn{7}{|c|}{ Fibrinogen beta gene, $F G B($ c.G455A) } \\
\hline & \multirow{2}{*}{$n$} & \multicolumn{2}{|c|}{ Allele frequency } & \multicolumn{3}{|c|}{ Genotype frequency } \\
\hline & & G & A & $\mathrm{G} / \mathrm{G}$ & $\mathrm{G} / \mathrm{A}$ & $\mathrm{A} / \mathrm{A}$ \\
\hline CVT patients & 49 & 77 (78.6\%) & $21(21.4 \%)$ & 30 (61.2\%) & 17 (34.7\%) & $2(4.1 \%)$ \\
\hline Control group & 36 & $62(86 \%)$ & $10(14 \%)$ & $26(72.2 \%)$ & $10(27.8 \%)$ & $0(0 \%)$ \\
\hline \multicolumn{7}{|c|}{ Integrin alpha (Gp1a glycoprotein) gene, ITGA2 (c.C807T) } \\
\hline & \multirow{2}{*}{$n$} & \multicolumn{2}{|c|}{ Allele frequency } & \multicolumn{3}{|c|}{ Genotype frequency } \\
\hline & & $\mathrm{C}$ & $\mathrm{T}$ & $\mathrm{C} / \mathrm{C}$ & $\mathrm{C} / \mathrm{T}$ & $\mathrm{T} / \mathrm{T}$ \\
\hline CVT patients & 49 & $83(84.7 \%)$ & $15(15.3 \%)$ & $37(75.5 \%)$ & $9(18.4 \%)$ & $3(6.1 \%)$ \\
\hline Control group & 36 & $61(85 \%)$ & $11(15 \%)$ & $26(72.2 \%)$ & $9(25 \%)$ & $1(2.8 \%)$ \\
\hline \multicolumn{7}{|c|}{ Platelet fibrinogen receptor (Gp3a glycoprotein) gene, ITGB3 (c.T1565C) } \\
\hline & \multirow{2}{*}{$n$} & \multicolumn{2}{|c|}{ Allele frequency } & \multicolumn{3}{|c|}{ Genotype frequency } \\
\hline & & $T$ & $\mathrm{C}$ & $\mathrm{T} / \mathrm{T}$ & $\mathrm{T} / \mathrm{C}$ & $\mathrm{C} / \mathrm{C}$ \\
\hline CVT patients & 49 & $83(84.7 \%)$ & $15(15.3 \%)$ & $35(71.4 \%)$ & $13(26.5 \%)$ & $1(2 \%)$ \\
\hline Control group & 36 & 67 (93\%) & $5(7 \%)$ & 31 (86.1\%) & 5 (13.9\%) & $0(0 \%)$ \\
\hline
\end{tabular}

Isolated CVT with polymorphic variants of the FXIIIA1 gene (c.G103T) in the homozygous or heterozygous state was observed in 5 patients (31\%), and the isolated CVT without any FXIIIA1 polymorphisms was present in 9 patients (27\%). Multiple CVT was diagnosed in 11 patients (69\%) with polymorphic variants of the FXIIIA1 gene (c.G103T) in the homozygous or heterozygous state, and in 24 patients (73\%) with no FXIIIA1 polymorphisms $(p=1.000)$.

Among patients with polymorphic variant of the MTR 2756 gene in heterozygous state, isolated CVT was observed in 10 patients (56\%), and multiple thrombosis was observed in 8 patients (44\%). In the absence of polymorphisms of the MTR 
Table 2. Frequency of alleles and genotypes of the folate metabolism genes pro-thrombogenic polymorphic variants

\begin{tabular}{|c|c|c|c|c|c|c|}
\hline \multicolumn{7}{|c|}{ Methylenetetrahydrofolate reductase gene, MTHFR (c.C677T) } \\
\hline & \multirow{2}{*}{$n$} & \multicolumn{2}{|c|}{ Allele frequency } & \multicolumn{3}{|c|}{ Genotype frequency } \\
\hline & & C & $\mathrm{T}$ & $\mathrm{C} / \mathrm{C}$ & $\mathrm{C} / \mathrm{T}$ & $\mathrm{T} / \mathrm{T}$ \\
\hline CVT patients & 44 & $66(75 \%)$ & $22(25 \%)$ & $25(56.8 \%)$ & $16(36.4 \%)$ & $3(6.8 \%)$ \\
\hline Control group & 36 & 60 (83\%) & 12 (17\%) & 26 (72.2\%) & 8 (22.2\%) & $2(5.6 \%)$ \\
\hline \multicolumn{7}{|c|}{ Methylenetetrahydrofolate reductase gene, MTHFR (c.A1298C) } \\
\hline & \multirow{2}{*}{$n$} & \multicolumn{2}{|c|}{ Allele frequency } & \multicolumn{3}{|c|}{ Genotype frequency } \\
\hline & & A & C & $\mathrm{A} / \mathrm{A}$ & $\mathrm{A} / \mathrm{C}$ & $\mathrm{C} / \mathrm{C}$ \\
\hline CVT patients & 48 & $83(86.5 \%)$ & $13(13.5 \%)$ & $37(77.1 \%)$ & $9(18.8 \%)$ & $2(4.2 \%)$ \\
\hline Control group & 36 & $64(89 \%)$ & $8(11 \%)$ & $29(80.6 \%)$ & $6(16.7 \%)$ & $1(2.8 \%)$ \\
\hline \multicolumn{7}{|c|}{ Methionine synthase reductase gene, MTRR (c.A66G) } \\
\hline & \multirow{2}{*}{$n$} & \multicolumn{2}{|c|}{ Allele frequency } & \multicolumn{3}{|c|}{ Genotype frequency } \\
\hline & & $A^{*}$ & $\mathrm{G}^{\star \star}$ & $\mathrm{A} / \mathrm{A}^{\star \star *}$ & $\mathrm{~A} / \mathrm{G}^{\star \star \star \star}$ & $\mathrm{G} / \mathrm{G}$ \\
\hline CVT patients & 46 & $63(68.5 \%)$ & $29(31.5 \%)$ & $22(47.8 \%)$ & $19(41.3 \%)$ & $5(10.9 \%)$ \\
\hline Control group & 36 & 64 (89\%) & $8(11 \%)$ & $29(80.6 \%)$ & 6 (16.7\%) & $1(2.8 \%)$ \\
\hline
\end{tabular}

Note: ${ }^{*}-\chi^{2}=9.631 ; p=0.002 ; \mathrm{OR}=0.272 ; 95 \% \mathrm{Cl} 0.115-0.640$;

${ }^{\star}-\chi^{2}=9.631 ; p=0.002 ; \mathrm{OR}=3.683+0.437 ; 95 \% \mathrm{Cl} 1.564-8.672$

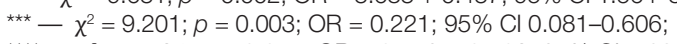

$\star * \star \star-\chi^{2}=5.784 ; p=0.017 ;$ OR $=3.519+0.538 ; 95 \% \mathrm{Cl} 1.225-10.104$

\begin{tabular}{|c|c|c|c|c|c|c|}
\hline \multicolumn{7}{|c|}{ Methionine synthase gene, MTR (c.A2756G) } \\
\hline & \multirow{2}{*}{$n$} & \multicolumn{2}{|c|}{ Allele frequency } & \multicolumn{3}{|c|}{ Genotype frequency } \\
\hline & & $A^{*}$ & $G^{* *}$ & $\mathrm{~A} / \mathrm{A}^{* * *}$ & $A / G^{* * * *}$ & $\mathrm{G} / \mathrm{G}$ \\
\hline CVT patients & 46 & $74(80.4 \%)$ & $18(19.6 \%)$ & $28(69.9 \%)$ & $18(39.1 \%)$ & $0(0 \%)$ \\
\hline Control group & 36 & $66(92 \%)$ & $6(8 \%)$ & $30(83.3 \%)$ & $6(16.7 \%)$ & $0(0 \%)$ \\
\hline
\end{tabular}

Note: * $\chi^{2}=4.079 ; p=0.044 ; \mathrm{OR}=0.374 ; 95 \% \mathrm{Cl} 0.140-0.998$;

${ }^{\star \star}-\chi^{2}=4.079 ; p=0.044 ; \mathrm{OR}=2.676+0.501 ; 95 \% \mathrm{Cl} 1.002-7.142$;

*** $-\chi^{2}=4.923 ; p=0.027 ; \mathrm{OR}=0.311 ; 95 \% \mathrm{Cl} 0.108-0.896$

${ }^{\star \star \star \star}-\chi^{2}=4.923 ; p=0.027 ; \mathrm{OR}=3.214+0.540 ; 95 \% \mathrm{Cl} 1.116-9.257$.

gene (c.A2756G), isolated CVT was diagnosed in 7 patients (25\%), and multiple CVT was diagnosed in $21(75 \%)$ patients $(p=0.06)$.

In homozygous and heterozygous carriers of $677 \mathrm{~T}$ allele of the MTRR gene, isolated CVT was detected in 5 patients (21\%), multiple CVT was detected in 19 patients (79\%). Among patients with no MTRR gene polymorphism isolated CVT was diagnosed in 8 patients (38\%), and multiple CVT was diagnosed in $13(62 \%)$ patients $(p=0.323)$

\section{DISCUSSION}

During our study, CVT was diagnosed in 24 patients (47.1\%) aged under 40. The ratio between males and females was $1: 1.2$. Slight prevalence of thrombosis among women of childbearing age could be explained by such risk factors as pregnancy, the use of contraceptives and hormone replacement therapy [22].

Prothrombogenic polymorphic variants of hemostatic genes were diagnosed in 94\% of patients. Most often, polymorphic variants of the PAl-1 gene (c.5G6754G) were observed, the product of which was involved in the fibrinolysis regulation. The presence of a polymorphic variant of such gene leads to an increase in the plasminogen activator inhibitor protein functional activity, which in turn contributes to an increased risk of thrombosis [23]. The frequency of heterozygous $4 \mathrm{G}$ allele at the -675 position of the PAl-1 gene in the population is $50 \%$, and the frequency of the homozygous allele is $26 \%$ [24]. In our study, $4 \mathrm{G}$ allele at the -675 position of the PAl-1 gene in heterozygous state $(5 \mathrm{G} / 4 \mathrm{G})$ was detected in $57.1 \%$ of patients, and in the homozygous state $(4 \mathrm{G} / 4 \mathrm{G})$ it was detected in $22.4 \%$ of patients.
For the PAl-1 gene, significant differences between the group of patients with CVT and the group of healthy people were observed in the distribution of both alleles and genotypes. In patients with the $4 \mathrm{G} / 4 \mathrm{G}$ genotype, the risk of CVT increased by 10.1 times $(\mathrm{OR}=10.132 ; 95 \% \mathrm{Cl}-1.243-82.573)$, and in patients with the $5 \mathrm{G} / 4 \mathrm{G}$ genotype it increased by 3.03 times $(\mathrm{OR}=3.030 ; 95 \% \mathrm{Cl}-1.223-7.507)$.

The effect of factor FXIIIA1 on CVT still remains unclear [25]. It is possible that G103T polymorphism of the FXIIIA1 gene is associated with the fibrin structure alterations. At a low concentration of fibrinogen, the blood clot density in patient with G103T polymorphism is high, while with an increase in the level of fibrinogen, the density of the blood clot, and therefore its stability, decrease. In the presence of $4 \mathrm{G} / 4 \mathrm{G}$ polymorphism of the PAl-1 gene the protective effect of G103T polymorphism of the FXIIIA1 gene decreases drastically [26].

Some authors note correlation of C677T polymorphism of the MTHFR gene and the risk of CVT [27, 28]. During our study, the prothrombogenic polymorphic variants of the methionine-homocysteine metabolism genes were detected in $86 \%$ of patients. Polimorphic variants of the MTRR (c.A66G) and MTR (A2756G) genes were most common. According to literature data, 66G allele of the MTRR gene frequency in the European population reaches 54\%. In our study the frequency of the allele was $31.5 \%$. Allelle $\mathrm{G}$ of $\mathrm{A66G}$ polymorphism of the MTRR gene increases the risk of CVT by 3.68 times $(\mathrm{OR}=3.683 ; 95 \% \mathrm{Cl}-1.564-8.672)$, allele $\mathrm{G}$ of $\mathrm{A} 2756 \mathrm{G}$ polymorphism of the MTR gene increases the risk by 2.676 times $(\mathrm{OR}=2.676 ; 95 \% \mathrm{Cl}-1.002-7.142)$ 
The presence of $A / G$ polymorphism of the MTRR gene increases the risk of CVT by 3.5 times (OR $=3.519$; 95\% $\mathrm{Cl}-1.225-10.104)$, and the presence of $A / G$ polymorphism of the MTR increases the risk by 3.2 times $(\mathrm{OR}=3.214 ; 95 \%$ $\mathrm{Cl}-1.116-9.257)$.

\section{CONCLUSION}

Gene polymorphisms 5G6754G (PAl-1), G103T (FXIIIA1), A66G (MTRR) and A2756G (MTR) carriage increases the risk of aseptic CVT and do not affect the thrombosis clinical manifestations.

\section{References}

1. Behrouzi R, Punter M. Diagnosis and management of cerebral venous thrombosis. Clin Med (Lond). 2018; 18 (1): 75-9. DOl: 10.7861/clinmedicine.18-1-75.

2. Maali L, Khan S, Qeadan F, Ismail M, Ramaswamy D, Hedna VS. Cerebral venous thrombosis: continental disparities. Neurol Sci. 2017; 38 (11): 1963-8. PubMed PMID: 28808795. DOI: 10.1007/ s10072-017-3082-7.

3. Lee DJ, Ahmadpour A, Binyamin T, Dahlin BC, Shahlaie K, Waldau B. Management and outcome of spontaneous cerebra venous sinus thrombosis in a 5-year consecutive single-institution cohort. J Neurointerv Surg. 2017; 9 (1): 34-8. DOI: 10.1136/ neurintsurg-2015-012237

4. Agrawal K, Burger K, Rothrock JF. Cerebral sinus thrombosis. Headache. 2016; 56 (8): 1380-9. DOI: 10.1111/head.12873.

5. Capecchi M, Abbattista M, Martinelli I. Cerebral venous sinus thrombosis. J Thromb Haemost. 2018;16 (10):1918-31. DOI: 10.1111/jth.14210

6. Coutinho JM, Zuurbier SM, Aramideh M, Stam J. The incidence of cerebral venous thrombosis: a cross-sectional study. Stroke. 2012; 43 (12): 3375-7. PubMed PMID: 22996960. DOI: 10.1161/ STROKEAHA.112.671453.

7. Janghorbani $M$, Zare M, Saadatnia M, Mousavi SA, Mojarrad M, Asgari E. Cerebral vein and dural sinus thrombosis in adults in Isfahan, Iran: frequency and seasonal variation. Acta Neurol Scand. 2008; 117 (2): 117-21. PubMed PMID: 18184347. DOI: 10.1111/j.1600-0404.2007.00915.x.

8. Coutinho JM, Zuurbier SM, Stam J. Declining mortality in cerebral venous thrombosis: a systematic review. Stroke. 2014; 45 (5): 1338-41. DOI: 10.1161/STROKEAHA.113.004666.

9. de Freitas GR, Bogousslavsky J. Risk factors of cerebral vein and sinus thrombosis. Front Neurol Neurosci. 2008; (23): 23-54.

10. Kashkoush Al, Ma H, Agarwal N, Panczykowski D, Tonetti D, Weiner GM, et al. Cerebral venous sinus thrombosis in pregnancy and puerperium: A pooled, systematic review. J Clin Neurosci. 2017; (39): 9-15. DOI: 10.1016/j.jocn.2017.02.046.

11. Bushnell C, McCullough LD, Awad IA, Chireau MV, Fedder WN, Furie $\mathrm{KL}$, et al. Guidelines for the prevention of stroke in women: a statement for healthcare professionals from the American Heart Association/American Stroke Association. Stroke. 2014; 45 (5): 1545-88. DOI: 10.1161/01.str.0000442009.06663.48.

12. Ilyas A, Chen CJ, Raper DM, Ding D, Buell T, Mastorakos P, et al. Endovascular mechanical thrombectomy for cerebral venous sinus thrombosis: a systematic review. J Neurointerv Surg. 2017; 9 (11):1086-92. DOI: 10.1136/neurintsurg-2016-012938.

13. McBane RD, Tafur A, Wysokinski WE. Acquired and congenital risk factors associated with cerebral venous sinus thrombosis. Thromb Res. 2010; 126 (2): 81-7. DOI: 10.1016/j.thromres.2010.04.015.

14. Martinelli I, Cattaneo M, Taioli E, De Stefano V, Chiusolo P, Mannucci PM. Genetic risk factors for superficial vein thrombosis. Thromb Haemost. 1999; 82 (4): 1215-7. PMID: 10544900.

15. Bushnell C, Saposnik G. Evaluation and management of cerebral venous thrombosis. Continuum (Minneap Minn). 2014; 20 (2 Cerebrovascular Disease): 335-51. DOI: 10.1212/01. CON.0000446105.67173.a8.

\section{Литература}

1. Behrouzi R, Punter M. Diagnosis and management of cerebral venous thrombosis. Clin Med (Lond). 2018; 18 (1): 75-9. DOI: 10.7861/clinmedicine.18-1-75.
16. Marjot T, Yadav S, Hasan N, Bentley P, Sharma P. Genes associated with adult cerebral venous thrombosis. Stroke. 2011; 42 (4): 913-8. DOI: 10.1161/STROKEAHA.110.602672.

17. Ferro JM, Bousser MG, Canhão P, Coutinho JM, Crassard I, Dentali $F$, et al. European Stroke Organization guideline for the diagnosis and treatment of cerebral venous thrombosis Endorsed by the European Academy of Neurology. Eur Stroke J. 2017; 2 (3): 195-221. DOI: 10.1177/2396987317719364.

18. Alshoabi SA. Cerebral venous sinus thrombosis: a diagnostic challenge in a rare presentation. Brain Circ. 2017; 3 (4): 227-230. DOI: 10.4103/bc.bc_27_17.

19. Gao L, Xu W, Li T, Yu X, Cao S, Xu H, et al. Accuracy of magnetic resonance venography in diagnosing cerebral venous sinus thrombosis. Thromb Res. 2018; (167): 64-73. DOI: 10.1016/j. thromres.2018.05.012.

20. Goyal G, Charan A, Singh R. Clinical Presentation, Neuroimaging Findings, and Predictors of Brain Parenchymal Lesions in Cerebral Vein and Dural Sinus Thrombosis: A Retrospective Study. Ann Indian Acad Neurol. 2018; 21 (3): 203-8. DOl: 10.4103/aian. AIAN_470_17.

21. Cai $H$, Ye X, Zheng W, Ma L, Hu X, Jin X. Pitfalls in the diagnosis and initial management of acute cerebral venous thrombosis. Rev Cardiovasc Med. 2018; 19 (4): 129-33. DOI: 10.31083/j. rcm.2018.04.4081.

22. Ferro JM, Canhão P, Aguiar de Sousa D. Cerebral Venous Thrombosis. Presse Med. 2016; 45 (12 Pt 2): e429-e450. PubMed PMID: 27816347. DOI: 10.1016/j.lpm.2016.10.007.

23. Schneider S, Kapelushnik J, Kraus M, El Saied S, Levi I, Kaplan DM. The association between otogenic lateral sinus thrombosis and thrombophilia - A long-term follow-up. Am J Otolaryngol. 2018; 39 (3): 299-302. PubMed PMID: 29530427. DOI: 10.1016/j. amjoto.2018.03.013.

24. Lichy C, Dong-Si T, Reuner K, Genius J, Rickmann H, Hampe T, et al. Risk of cerebral venous thrombosis and novel gene polymorphisms of the coagulation and fibrinolytic systems. J Neurol. 2006; 253 (3): 316-20. PubMed PMID: 16155788. DOI: 10.1007/s00415-005-0988-4.

25. Li B, Heldner MR, Arnold M, Coutinho JM, Zuurbier SM, Meijers JCM, et al. Coagulation Factor XIII in Cerebral Venous Thrombosis. TH Open. 2019; 3 (3): e227-e229. DOI: 10.1055/s0039-1693487.

26. Bagoly Z, Muszbek L. Factor XIII: What does it look like? J Thromb Haemost. 2019; 17 (5): 714-6. DOI: 10.1111/jth.14431.

27. Ali Z, Troncoso JC, Fowler DR. Recurrent cerebral venous thrombosis associated with heterozygote methylenetetrahydrofolate reductase C677T mutation and sickle cell trait without homocysteinemia: an autopsy case report and review of literature. Forensic Sci Int. 2014; (242): e52-e55. DOI: 10.1016/j.forsciint.2014.07.007.

28. Ghaznavi H, Soheili Z, Samiei S, Soltanpour MS. Association study of methylenetetrahydrofolate reductase C677T mutation with cerebral venous thrombosis in an Iranian population. Blood Coagul Fibrinolysis. 2015; 26 (8): 869-73. DOI: 10.1097/ MBC.0000000000000292.

2. Maali L, Khan S, Qeadan F, Ismail M, Ramaswamy D, Hedna VS. Cerebra venous thrombosis: continental disparities. Neurol Sci. 2017; 38 (11): 1963-8. PubMed PMID: 28808795. DOI: 10.1007/s10072-017-3082-7. 
3. Lee DJ, Ahmadpour A, Binyamin T, Dahlin BC, Shahlaie K, Waldau B. Management and outcome of spontaneous cerebral venous sinus thrombosis in a 5-year consecutive single-institution cohort. J Neurointerv Surg. 2017; 9 (1): 34-8. DOI: 10.1136/ neurintsurg-2015-012237.

4. Agrawal K, Burger K, Rothrock JF. Cerebral sinus thrombosis. Headache. 2016; 56 (8): 1380-9. DOI: 10.1111/head.12873.

5. Capecchi M, Abbattista M, Martinelli I. Cerebral venous sinus thrombosis. J Thromb Haemost. 2018;16 (10):1918-31. DOI: 10.1111/jth.14210.

6. Coutinho JM, Zuurbier SM, Aramideh M, Stam J. The incidence of cerebral venous thrombosis: a cross-sectional study. Stroke. 2012; 43 (12): 3375-7. PubMed PMID: 22996960. DOI: 10.1161/ STROKEAHA.112.671453.

7. Janghorbani M, Zare M, Saadatnia M, Mousavi SA, Mojarrad M, Asgari E. Cerebral vein and dural sinus thrombosis in adults in Isfahan, Iran: frequency and seasonal variation. Acta Neurol Scand. 2008; 117 (2): 117-21. PubMed PMID: 18184347. DOI: 10.1111/j.1600-0404.2007.00915.x.

8. Coutinho JM, Zuurbier SM, Stam J. Declining mortality in cerebral venous thrombosis: a systematic review. Stroke. 2014; 45 (5): 1338-41. DOI: 10.1161/STROKEAHA.113.004666.

9. de Freitas GR, Bogousslavsky J. Risk factors of cerebral vein and sinus thrombosis. Front Neurol Neurosci. 2008; (23): 23-54.

10. Kashkoush Al, Ma H, Agarwal N, Panczykowski D, Tonetti D, Weiner GM, et al. Cerebral venous sinus thrombosis in pregnancy and puerperium: A pooled, systematic review. J Clin Neurosci. 2017; (39): 9-15. DOI: 10.1016/j.jocn.2017.02.046.

11. Bushnell C, McCullough LD, Awad IA, Chireau MV, Fedder WN, Furie $\mathrm{KL}$, et al. Guidelines for the prevention of stroke in women: a statement for healthcare professionals from the American Heart Association/American Stroke Association. Stroke. 2014; 45 (5): 1545-88. DOI: 10.1161/01.str.0000442009.06663.48.

12. Ilyas A, Chen CJ, Raper DM, Ding D, Buell T, Mastorakos P, et al. Endovascular mechanical thrombectomy for cerebral venous sinus thrombosis: a systematic review. J Neurointerv Surg. 2017; 9 (11):1086-92. DOI: 10.1136/neurintsurg-2016-012938.

13. McBane RD, Tafur A, Wysokinski WE. Acquired and congenital risk factors associated with cerebral venous sinus thrombosis. Thromb Res. 2010; 126 (2): 81-7. DOI: 10.1016/j.thromres.2010.04.015.

14. Martinelli I, Cattaneo M, Taioli E, De Stefano V, Chiusolo P, Mannucci PM. Genetic risk factors for superficial vein thrombosis. Thromb Haemost. 1999; 82 (4): 1215-7. PMID: 10544900.

15. Bushnell C, Saposnik G. Evaluation and management of cerebral venous thrombosis. Continuum (Minneap Minn). 2014; 20 (2 Cerebrovascular Disease): 335-51. DOI: 10.1212/01. CON.0000446105.67173.a8.

16. Marjot T, Yadav S, Hasan N, Bentley P, Sharma P. Genes associated with adult cerebral venous thrombosis. Stroke. 2011; 42 (4): 913-8. DOI: 10.1161/STROKEAHA.110.602672.
17. Ferro JM, Bousser MG, Canhão P, Coutinho JM, Crassard I, Dentali $F$, et al. European Stroke Organization guideline for the diagnosis and treatment of cerebral venous thrombosis Endorsed by the European Academy of Neurology. Eur Stroke J. 2017; 2 (3): 195-221. DOI: 10.1177/2396987317719364.

18. Alshoabi SA. Cerebral venous sinus thrombosis: a diagnostic challenge in a rare presentation. Brain Circ. 2017; 3 (4): 227-230. DOI: 10.4103/bc.bc_27_17.

19. Gao L, Xu W, Li T, Yu X, Cao S, Xu H, et al. Accuracy of magnetic resonance venography in diagnosing cerebral venous sinus thrombosis. Thromb Res. 2018; (167): 64-73. DOI: 10.1016/j. thromres.2018.05.012.

20. Goyal G, Charan A, Singh R. Clinical Presentation, Neuroimaging Findings, and Predictors of Brain Parenchymal Lesions in Cerebral Vein and Dural Sinus Thrombosis: A Retrospective Study. Ann Indian Acad Neurol. 2018; 21 (3): 203-8. DOI: 10.4103/aian. AIAN_470_17.

21. Cai $H_{\text {, }}$ Ye $\bar{X}$, Zheng $W, M a ~ L, ~ H u X$, Jin X. Pitfalls in the diagnosis and initial management of acute cerebral venous thrombosis. Rev Cardiovasc Med. 2018; 19 (4): 129-33. DOI: 10.31083/j. rcm.2018.04.4081.

22. Ferro JM, Canhão P, Aguiar de Sousa D. Cerebral Venous Thrombosis. Presse Med. 2016; 45 (12 Pt 2): e429-e450. PubMed PMID: 27816347. DOI: 10.1016/j.Ipm.2016.10.007.

23. Schneider S, Kapelushnik J, Kraus M, El Saied S, Levi I, Kaplan DM. The association between otogenic lateral sinus thrombosis and thrombophilia - A long-term follow-up. Am J Otolaryngol. 2018; 39 (3): 299-302. PubMed PMID: 29530427. DOI: 10.1016/j. amjoto.2018.03.013.

24. Lichy C, Dong-Si T, Reuner K, Genius J, Rickmann H, Hampe T, et al. Risk of cerebral venous thrombosis and novel gene polymorphisms of the coagulation and fibrinolytic systems. $J$ Neurol. 2006; 253 (3): 316-20. PubMed PMID: 16155788. DOI: 10.1007/s00415-005-0988-4.

25. Li B, Heldner MR, Arnold M, Coutinho JM, Zuurbier SM, Meijers JCM, et al. Coagulation Factor XIII in Cerebral Venous Thrombosis. TH Open. 2019; 3 (3): e227-e229. DOI: 10.1055/s0039-1693487.

26. Bagoly Z, Muszbek L. Factor XIII: What does it look like? J Thromb Haemost. 2019; 17 (5): 714-6. DOI: 10.1111/jth.14431.

27. Ali Z, Troncoso JC, Fowler DR. Recurrent cerebral venous thrombosis associated with heterozygote methylenetetrahydrofolate reductase C677T mutation and sickle cell trait without homocysteinemia: an autopsy case report and review of literature. Forensic Sci Int. 2014; (242): e52-e55. DOI: 10.1016/j.forsciint.2014.07.007.

28. Ghaznavi H, Soheili Z, Samiei S, Soltanpour MS. Association study of methylenetetrahydrofolate reductase C677T mutation with cerebral venous thrombosis in an Iranian population. Blood Coagul Fibrinolysis. 2015; 26 (8): 869-73. DOI: 10.1097/ MBC.0000000000000292. 